\title{
CORONAVIRUS DISEASE-19: A HOLISTIC PERSPECTIVE
}

\author{
P00JA RAJ, KIRTI BHATI*, RAVINDRA PATWARDHAN
}

Department of Swasthavritta and Yoga, Bharati Vidyapeeth (Deemed to be University), College of Ayurveda, Pune, Maharashtra, India. Email: kirti.bhati@bharatividyapeeth.edu

Received: 30 November 2020, Revised and Accepted: 04 January 2021

\section{ABSTRACT}

Even when the predictions of effective specific antiretroviral treatment improved after 1996, many scientists and health professionals stayed committed to a dominant role of prevention over treatment and care. With the growing need for vaccines and safer drugs, greater attention is now toward the traditional system of medicine. Charak Samhita explains epidemics and its etiological factor in Janapadodhwamsa Adhyay of Vimansthan 3. Ayurveda and Yoga have immersed to have great combat with coronavirus disease (COVID-19) to maintain your overall health. The present study is aimed to get, a holistic approach that suggests a preventive approach and strengthening of Bala and Oja. Ayurveda and Yoga give importance to physical immunity and also psychological immunity as well. By following Rasayan, Sadvritta, Acharasayan, Astanga Yoga and Satvik Karma one manages a proper balance and Tridosha along with physical and mental health. There is a need to explore the holistic care modules stated in different Ayurvedic classical texts and Yoga for COVID-19.

KEYWORD: Coronavirus disease-19, Janapadodhwamsa, Ayurveda, Holistic, Yoga, Pandemic.

\section{INTRODUCTION}

Global momentum about coronavirus disease (COVID-19) is unabated, and a second wave is foreseen. We have to learn from severe acute respiratory syndrome (SARS) epidemics that better strategies and medical care modules for public health are required [1]. The W.H.O. has declared COVID-19 as Public Health Emergency of International Concern [2]. A total of 218 countries and territories and 2 conveyances around the world have reported a total of 61,308,161 confirmed cases of the coronavirus COVID-19 to date and still counting, a death toll of $1,437,835$ deaths. India is the $2^{\text {nd }}$ most affected country by count in the world after the United States [3]

COVID-19 is a contagious respiratory and vascular disease, caused by SARS coronavirus 2 [4]. People with the same infection may have different symptoms, and their symptoms may change overtime (Table 1).

High-risk groups added another challenge for the medical professionals as their prognosis was very poor and life threatening. The presence of comorbidities such as hypertension, diabetes mellitus, chronic obstructive pulmonary diseases, and old age leads to poor clinical outcomes in COVID-19 patients, in such situations, preventive measures play a better role rather than curative modalities [5]. It is a conceptual and literary-based study in the management of COVID-19 through Ayurveda and Yoga and gives a ray of hope that traditional medicines can also prove to be a boon in managing one's health and lifestyle along with mental harmony without which attainment of Dharma, Artha, Kama, and Moksha is not possible. From Ayurveda Outlook, Swasthya is the harmonious relationship between the Mana, Atma, Sharir, and Desha. Swasthya of an individual depends on the environment he/she lives in. Many factors influence disease condition in Ayurveda one of which is Asadharan-Sadharan. Asadharan is a disease caused by one's lifestyle habits and eating habits or genetics and Sadharan is a disease caused by susceptible to any disease which affects a large population and it Janapadodhwamsa. Another classification of disease is Nija and Agantuj [6].

Charka Samhita has mentioned Janapadodhwamsa (Epidemic) in (Vimansthan, Chapter-3) and defines vyadhikshamatva (immunity) as the ability to prevent and arrest the progression of the disease for sustaining homeostasis [7]. Sushruta Samhita (SutraSthana, Chapter-6 verse 19-20) described Janapadodhwamsa [8]. Yoga is an art based on the Manas, Atma, and Sharir [9]; the classical text Yoga Vasishta [10] (Book 6, Chapter 81) has described a healthy person as one who is free from physical disease and stable from the mind. Yoga proclaims that humans can experience Panchakosh for their existence. Prana is a vital force that fills Panchakosh, nourishes, and sustains them [5]. Ayurveda has described the concept of Pancha Prana/Pancha Vayu which looks after the working and stability of body, mind, and spirit.

Mental health is more than the absence of psychological disorders. Enhancement of psychoimmunity is as important as improving general immunity [11]. The W.H.O defines mental health as a state of well-being in which the individual realizes his or her abilities, can cope with the normal stresses of life, can work productively and fruitfully, and can make a contribution to his or her community [12]

Through Anukta Vyadhi and the involvement of dorsal-dushya samurachana and by evaluating symptoms of successful management of disease understanding, Nidan Panchak is important which includes Nidan (etiology), Purvaroopa (prodromal features), Rupa (signssymptoms), Upashaya-Anupshaya (relieving and aggravating factors), and Samprapti [13]. The integrative approach of Ayurveda and Yoga provides a balancing of Dosha in the body and enhancing one functional and structural activity useful in maintaining homeostasis and attainment of health.

\section{COVID-19 METAPHOR IN AYURVEDA}

Different terms mentioned in Ayurveda for Janapadodhwamsa showed in (Table 2), they are modes for spreading of the disease. Contamination of Vayu (air), Jala (water), Desha (place or soil), and changes in Kala (season) is responsible for the Janapadodhwamsa. Characteristics of contaminated Vayu, Udaka, Desh, and Kala are stated in Table 3. Ayurveda has also explained the mode of transmission and comparative study as stated in Table 4.

Acharya Charaka has mentioned Dharma and pradhyaparadh as the root cause of any epidemics to occur. Acharya Sushruta has mentioned about Aupsarigika Rogas as the main cause of the spread of disease [5].

These modes of transmission are still relevant for the current pandemic vantage point $[6,7]$. 
COVID-19 symptoms are probably like a Sannipatik Jawar in Ayurveda and its various avastha (stages) depending on its severity stated in Table 5 [8]. If the main Avastha (stage) is controlled, disease will not manifest further and can be prevented [9].

Ayurveda believes that manifestation of the disease is due to an imbalance of tridosha which induces disease condition in the body and creates an environment for developing the disease. Most prominent causes are Pranjyapradha, Asatmendriyartha Samyoga, and Parinama/ Kala. Incorrect adoptions made by individuals are the contributing factors for Pranjyaparadha which includes violation of actions verbally, mentally, and physically which aggravates tridosha along with Rajas and Tamas disease. Asatmendriyartha Samyoga means improper contact of senses with their objects which result in overstimulation of sensory activity. Parinama/Kala is a seasonal influence on Belgmwar [11].

Anitya and Adharma are the setback of disease. Along with the abovestated factors, other diseases manifesting causes are Shastraprabhavaja Abhishanghaja, and Abhishapaja. In epidemiology, epidemiological triad which includes a host, agent, and environment handles the causation of the disease [12,13]. Shatakriyakala in Ayurveda explains well about the stage-wise manifestation of disease and if the early prognosis is done, disease can be prevented from aggravating [14].

Ayurveda etiopathogenesis of COVID-19 explained in the chart (Table 6).

Table 1: COVID-19 symptoms depending on severity: [4]

\begin{tabular}{|c|c|c|}
\hline Most common & Less common & Severe \\
\hline Fever (88\%) & $\begin{array}{l}\text { Loss of appetite } \\
(40-84 \%) \text {, }\end{array}$ & $\begin{array}{l}\text { Shortness of breath or } \\
\text { difficulty in breathing }\end{array}$ \\
\hline Dry cough (68\%), & $\begin{array}{l}\text { Shortness of breath } \\
(31-40 \%) \text {, }\end{array}$ & Continuous chest pain \\
\hline \multirow[t]{8}{*}{$\begin{array}{l}\text { Tiredness } \\
(40-70 \%)\end{array}$} & $\begin{array}{l}\text { Muscles ache and } \\
\text { pain }(11-35 \%)\end{array}$ & \multirow[t]{8}{*}{$\begin{array}{l}\text { Loss of speech or } \\
\text { movement }\end{array}$} \\
\hline & $\begin{array}{l}\text { Loss of smell } \\
(15-30 \%)\end{array}$ & \\
\hline & Sore throat, diarrhea & \\
\hline & $(3 \%)$ & \\
\hline & $\begin{array}{l}\text { Conjunctivitis, } \\
\text { discoloration of }\end{array}$ & \\
\hline & fingers and toes, & \\
\hline & headache (8\%), & \\
\hline & Rash on the skin & \\
\hline
\end{tabular}

Table 2: Terms used by acharyas for epidemic in Ayurveda

\begin{tabular}{ll}
\hline Acharyas & Synonyms \\
\hline Charaka & Janapadodhwamsa \\
Sushruta & Marak \\
Bhel & Janamaar \\
\hline
\end{tabular}

COVID-19 symptoms show similarity to Pranavaha Sroatas according to signs and symptoms. It is samprapti according to Shatkriyakala and Rtu sandhi $[6,7,15,16]$.

COVID-19 can relate to Abhinayas Jwara which is a type of Sannipataj Jwara which effects Rasavaha and Pranavaha Srotas, it can also relate to Bhutabhishanga Jwara which is a kind of Agantujha Jwara and related to microorganisms which cause disease in the body when gets vitiated. Acharya Sushruta in Nidana Sthan (chapter 5, verse 33-34) had described Aupsargika Roga and Sansargaja Roga which when gets vitiated can cause epidemics or pandemics like situation [17].

Psychoimmunity has not been paying attention by the regulatory bodies which would be extremely important pre- and post-COVID-19 time for reducing the traumatic effect of the pandemic [18]. Tools to enhance psychological immunity are as follows:

\section{RASAYAN ROLE IN COVID-19}

Ayurvedic classical texts guide us on how to maintain health in epidemics through Rasayan therapy. The drug must be collected before the outbreak of any epidemics so that it can later be used for treatment as during Janapadodhwamsa everything gets polluted and ineffective (Table 7).

Out of all these, Namittika Rasayan is helpful as it makes cells potent to the disease-causing pathogen [19]. The herbs are mixed during the preparation of Rasayan they act as an immunomodulator and restore and balance immunity of the body. Rasayan is an add-on treatment for current pandemic prophylaxis [1]. Phytochemicals in Rasayan herbs possibly restore pulmonary health by strengthening endothelial dysfunction and reducing oxidative stress [20]. Rasayan drugs such as Ashwagandha, Guduchi, Yastimadhu, and Amalaki. It has shown commendable results in boosting of immunity in COVID-19 (1). Administration of these herbs in specific dosage forms or the formulations prepared from them under Ayurvedic physician's guideline can be a strong measure of prevention of the further spread of COVID-19 among healthy individuals [21,22]. Rasayan immunomodulation action promotes health by promoting strength to srotas, boosting of Agni, strengthening of the physique, nourishing the skin, gives longevity, providing good memory, and intellect, it acts as a rejuvenator in a diseased person [23].

\section{ACHAR RASAYAN (CODE OF CONDUCT) ROLE IN COVID-19}

Acharya Charaka described Achara Rasayana in Rasayana Adhyaya Chaturtha Pada of Chikitsa Sthana. Health is more than just a disease. This is a medicine which everyone can use in daily life to maintain overall health. Achar (behavioral) Rasayana is a Code of Conduct as per Ayurveda such as truthfulness, non-violence, lack of anger, talking with pleasing words, having sense concentrated to spirituality, conscious, less egoistic, sharing more demanding less, planning well to achieve a better future, a follower of religion, intake of milk and ghee in the daily diet, be respectful, avoid cruelty, respect your elders and old peoples, be merciful, do charity, be patient, avoid exertion, be pure, believe in God, be calm, and peaceful [24] need to be followed by everyone to maintain

Table 3: Characteristics of dushit vayu, jala, desha, and kala

\begin{tabular}{|c|c|c|c|}
\hline Vayu & Jala & Desha & Kala \\
\hline $\begin{array}{l}\text { Air not in compliance with the } \\
\text { current season (Rtu) }\end{array}$ & Stinky and fetid & Abnormal color, odor, taste, touch & $\begin{array}{l}\text { Abnormal if it exhibits excessive or } \\
\text { deficient characteristics }\end{array}$ \\
\hline Calm/violent & Abnormal color & Excess dumpy & $\begin{array}{l}\text { Early change of season with an } \\
\text { excess of hotness or coldness }\end{array}$ \\
\hline Excess Rough & Abnormal touch & $\begin{array}{l}\text { The land has an abundance of serpents, beasts, } \\
\text { mosquitoes, locusts, flies, etc. }\end{array}$ & \\
\hline Excess Cold & Abnormal taste & $\begin{array}{l}\text { A land where people's virtues such as religion, truth, } \\
\text { modesty, custom, character have either declined or } \\
\text { lost }\end{array}$ & \\
\hline Excess hot & Excessively sticky & Smoky air & \\
\hline Excess dry & Devoid of source & Land is disconcerting & \\
\hline
\end{tabular}


overall health and not just merely a disease-free body. They are brain tonics as it nourishes our thoughts which is expressed in our deeds and thoughts beneficial for us as well as people around us [5]. Positive mind and a healthy body are the sources of happiness. Satvajaya chikitsa needed for those with low and poor will power [25].

\section{AYURVEDIC DAILY PRACTICES FOR PREVENTION OF COVID-19}

Hasta-Pada Dhawan to avoid the spread of infection which one gets from outside, Aushadhi Youkta Jala Snana to avoid the spread of infection which one gets from outside [6], Abhyanga to strengthen skin

Table 4: Comparative study of mode of transmission

\begin{tabular}{lll}
\hline S. No. & Ayurveda & Modern science \\
\hline 1. & Prasanga & Mutual contact \\
2. & Gatrasansparsha & Skin to skin touch \\
3. & Sahabhojana & Sharing food \\
4. & Nihashwasa & Exhaled air \\
5. & Shashaiya & Sleeping closely \\
6. & Asana & Sitting close to each other \\
7. & Vatra & Clothes \\
8. & Malay & Using handkerchief and towels \\
9. & Anulepana & Using paste of chandana on the body \\
& & after bath \\
\hline
\end{tabular}

by increasing blood flow the sweating caused during massage helps to remove toxins from the blood, Kavala-Gandusha cleansing effect an oral cavity and removing extra mucous. Coronaviruses are abundant in the nasal and mouth mucosa, removing them may decrease the severity. Nasya disinfection of the nose as well as it reaches to the bloodstream and also helps in decreasing respiratory manifestations $[11,26]$.

Fumigation of house for the purification of Vikrut Vayu and Desh can be correlated with Dhupana and Homa. [25]. Vaad Chikitsa (sound therapy) Sushruta Samhita (Kalpa Sthana Chapter-3/13-15) during Janapadodhwamsa foods get contaminated during this period and if that food, eating it will be harmful, so to get rid of poisonous food various paste need to apply to various instruments to produce sound [27].

Sutakakala days avoid contact with the persons of the society just after delivery of a child by the mother which probably helps the newborn and mother protected from getting infected. In Ashtanga Sangrah "Sanchariroga" term has been used for referring of communicable disease spread from person to person [9].

\section{AAHAR FOR VYADHIKSHAMATAV IN COVID-19}

Undernutrition due to inadequate dietary intake of nutrients is one of the reasons, which weakens the immune defense system. It also reduces its

Table 5: Correlation of symptoms

\begin{tabular}{|c|c|c|c|}
\hline Avastha & COVID-19 & Nidana Panchak [10] & Sannipatik Jwara \\
\hline 1 & Fever, cough, sore throat, myalgia & Samanya Purvarupa & Jwara, Kasa, Gala Shoth, Angamarda \\
\hline 2 & Pneumonia, shortness of breath, sputum production & Rupa & Shwasa, Raktapitta, Kaphasthivam \\
\hline 3 & Respiratory failure, multiorgan failure, septic shock & Beda Avastha & Jwara, Dhatupaaka \\
\hline
\end{tabular}

Table 6: Samprapti of COVID-19 in Ayurveda

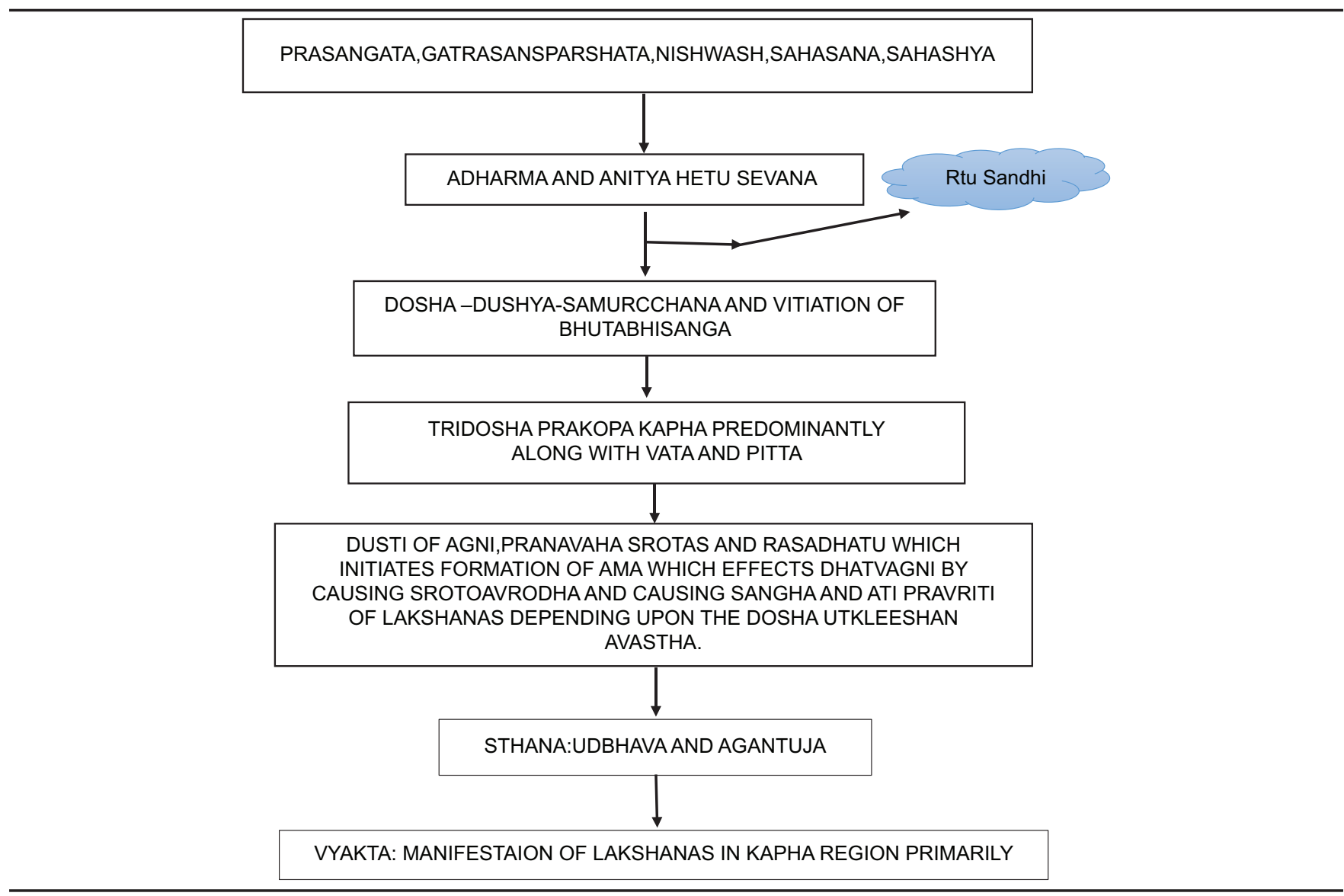


Table 7: Classification of rasayan

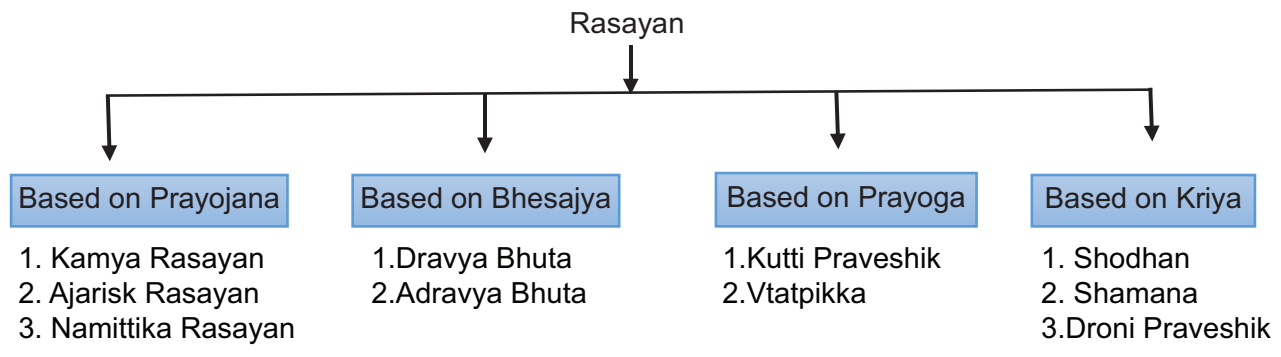

strength to prevent disease-causing pathogens' entry into the body, thus making people more susceptible to various infections [13]. Trividha Kukshi Ahara improves metabolism and the nutrition of the body, thus it increases immunity, which is an important factor for the prevention of COVID-19 [18]. Important vitamins that act on boosting immunity and keeping infectious diseases at bay are obtained from food. Avoid stale foods [8], humans have known food before microbes have started to cause disease Aahar is the building block of one immunity system and not even that it maintains normal functioning of various systems as well. Hence, a balanced diet took at the right amount in the right quantity in the right combination of foods with the right mindset boost immunity and provides strength to fight to any disease [28], Consumption of wholesome and unwholesome Ahara without following the factors stated in Ashta Ahara Vidhi Visheshayatana stated in Ayurveda which includes Prakriti, Karana, Samyoga, Rashi, Desha, Kala and Upyogasamsth give rise to Gurutva, Shrama, Alasya, Sanchaya, Parigrha, Lobha, Droha which are common attributes of anuvartavachna (falsehood) and one of the leading cause of Adhrma which give further rise to Krodha, Aahankar, Dwesh, Bhaya, Shoka and Chinta which are common attributed of diseased person who loses control over his need to be fulfilled and eats more than required and weakens immunity which deteriorates physical health one day and lately mental health gets affected [29], [30].

\section{SADVRITTA ROLE IN COVID-19}

Sadvritta plays an important role in keeping oneself healthy and in the prevention of disease. Sadvrittas apply to people of all age groups, at all times, and all places.

\section{Types of sadvritta [31,32]}

These codes of conduct include the following groups.

1. Vyavaharika sadvritta (Ethical codes of conduct)

2. Samajika sadvritta (Social codes of conduct)

3. Manasika sadvritta (Mental codes of conduct)

4. Dharmika sadvritta (Moral codes of conduct)

5. Sharirika Sadvritta (Physical codes of conduct).

\section{VYAVAHARIKA SADVRITTA}

- Speak the truth always which does not hurt people around you and is beneficial for all

Whenever anyone goes for a walk, one should carry an umbrella

- Do not over-exercise. Because proper exercise brings about lightness, ability to work, stability, resistance to discomfort, stimulates the power of digestion. Excessive physical exercise gives rise to tiredness, exhaustion, and excessive thirst, bleeding from different parts of the body, darkness in front of eyes, cough, fever, and vomiting

- Sleep on the comfortable cot as it relieves fatigue, normalizes Vata, aphrodisiac, bestows contentment

- Sleep normally and do not stay awake for a long time in the night. Because Sleep enjoyed for proper time boost nourishment, good color (complexion), strength, enthusiasm, and maintains normalcy of the tissues

- Do not take a bath till your body reaches a normal body temperature after exertion, not before washing the mouth, and not in nudity. After taking bath should not repeat, the last clothes wore.

\section{SAMAJIK SADVRITTA}

- Be friendly, pacify the anger, and console those who are frightened, help the poor, be truthful, peaceful, and watch your tongue before you speak badly to anyone

- Always respect guests and show hospitality towards them

- Avoid combing hair in a public place. Do not pick your teeth or finger the nose or ear in the presence of people

- One should not laugh loudly and should not remove flatus with sound

- Always covered mouth by hand during coughing and sneezing. Because various types of droplet infections passed from one person to another person through fluids from the mouth and nose secretions. By covering our mouth, we are blocking the germs that are expelled during cough and sneeze

- Do not use unwashed clothes dirty or uncomfortable clothes, clothes worn by others, not proper to the season, occasion, or clothes made from unnatural fiber. The wearing of clean dress promotes desires, reputation, longevity, and prevents the inauspiciousness. It brings about pleasure, grace, competence, and a good look

- One should not abandon relatives, affectionate ones who have helped in times of difficulty, and who know the deep secrets of the family

- One should not expose genital or sexual organs or parts of the body

- Should not have a relationship with women, friends, and servants of bad conduct.

\section{MANSIKA SADVRITTA}

- One should not indulge in any activity without verifying it properly

- Keep control over your sense organ and do not allow them to control you

- Take your time to analyze things properly before landing up to any conclusion

- Do not feel excessively exhilarated in achieving and depressed at the loss.

\section{DHARMIKA SADVRITTA}

- A person should not go out without touching the gems, feet of a respectable person, auspicious things, and flowers. Always wear auspicious herbs that are protective of evil such as Tulsi, Sahadevi, and Rudraksha. Everyone should pay respect to the Gods, cows, teachers (preceptors) older people, and those who have accomplished spiritual perfection

- Do not wander in an unknown place and prohibited area at night. Do not take shelter at night time in temples, under holy trees, at meeting place of four roads, garden, burial ground, and places of the slaughterhouse

- Do not eliminate sputum, flatus, feces, and urine in front of the wind, fire, water, the moon, the sun, and the teachers.

\section{SHARIRIKA SADVRITTA}

- Always wear gems and ornaments. Because it adds to the prosperity, auspiciousness, longevity, and grace and prevents the danger from snakes, evil spirits, etc. It is pleasant and charming. It is also conductive of $\mathrm{Oja}$

- Followers of a routine of oil massage on the head, ears, nostrils, and feet every day 
- Always follow a routine of hair cutting, nail cutting, and shaving at least 3 times in a fortnight. Keep the nails and hair clean and welltrimmed each fortnight or as per need. Because hand and nail pick up dirt and infectious agent easily as it comes in contact with various things, so washing of hand and removal of the nail at a regular interval is mandatory especially to prevent the diseases transmitted through the fecal-oral route

- A bath once or twice daily, according to the season as bathing is auspicious and aphrodisiac. It removes fatigue, sweating, increases self-confidence, and emotional well-being. Bathing helps to remove dirt and unpleasant body odor from the body. It promotes vitality in the body and increases longevity. It brings about strength in the body and is an aid par excellence for the improving of Ojas. It also helps to stay fit and good looking. Bathing improves blood circulation and boosts the immune system

- The footwear selection should be as per our physical structure, geographic condition, season, and type of job. Putting on footwear is good for the eyes, vision, and skin. Removes discomfort of the feet, bestows strength, good for valor, and sexual desire [14].

\section{NIDRA ROLE IN COVID-19}

Sleep is important for general psychological well-being. It is also correlated with a reduction in people with the psychotic condition [18] and the healing of the body timely and routinely.

\section{BRAMCHARYA ROLE IN COVID-19}

Brahmacharya (Celibacy) in Ayurveda for mental health and psychoimmunity. The action, thoughts, and character of a person need boosting with spiritual life and should live in continuous harmony with the supreme soul [5].

\section{COVID-19: YOGA PERSPECTIVE}

The psychological impact of COVID-19 is effecting individual health now, and then just thought of fear of death is giving people anxiety, stress, and psychological disturbances which delays the recovery of the human body from the disease and making healthy human diseased [33,34]. Spiritual health is the bonding between physical, mental, and social health which is achieved with the help of Yoga [35].

Yoga workout routines have a holistic impact and convey body, mind, recognition, and soul into balance. Pranayama categorized into different types depending on the frequency, degree of depth used, forms of openings used, and adding physical manipulations [36]. Yoga and its different modalities have immersed to be a different medicinal impact on the community which is positively serving humanity [37]. We are lucky to have Yoga in our lives, and [21] such a divine heritage that is booming in this present pandemic condition to serve mankind with its hearing aids. The classical text Yoga Vasishta describes a healthy person as one who is free from physical disease and erroneous affections of the mind [16]. Yoga places great importance on a proper and healthy lifestyle whose main components are Achar, Vichar, Aahar, and Vihar.

Yogic exercises recharge the body with cosmic energy and facilitate as follows:

- Attainment of perfect equilibrium and harmony

- Promotes self-healing

- Removes negative blocks from the mind and toxins from the body

- Enhances personal power

- Increases self-awareness

- Helps with attention, focus, and concentration, especially important for children

- Reduces stress and tension in the physical body by activating the parasympathetic nervous system $[17,38,39]$.

\section{SURYA NAMASKAR}

The salutation of the sun is done early morning empty stomach. It consists of 12 different yoga poses (Pranamasan, Hasta uthanasana,
Hasta Padasana, Ashwasanchalan Asana, Chaturanga Dhandaasana, Ashtanga Namaskara, Bhujanga Asana, Adhomukha Shavasana, Ashwasanchalan, Hastapada Asana, Hasta Uttana Asana, and Pranama Asana in a set of two beneficial for immunity, physical, and mental growth), it improves blood circulation, strengthens the core, beneficial for hair, weight loss, improves elasticity, and flexibility of body [39].

Asanas that specifically support healthy lungs include: Virasana (Hero/Warrior/Champion pose) Supta Virasana (supta = laying down) Paryankasana (Couch pose) Urdhva Dhanurasana (Upward Bow Pose), and Asanas for recovery after pneumonia include Salamba Sirsana (salamba = support, Sirsa $=$ head, "Headstand Pose") Salamba Sarvangasana, Halasana (Plow Pose) Paschimottanasana, Uttanasana (Forward Bend), Virasana, Parvatasana, Matsyasana (Fish Pose) [40-42].

\section{PRANAYAM [36,43]}

\section{Anulome-vilome Pranayam}

Anuloma stands for "with the grain" and Viloma stands for "against the grain." This is the best pranayama to maintain equilibrium over the $T r i$ doshas that would increase immunity. It consists of holding one nostril closed while inhaling, then holding the other nostril closed while expiring. The process is then turned upside down and repeated.

\section{Impact}

It releases stress from the mind and body effectively and helps to relax. It helps to harmonize the left and right hemispheres of the brain, which correlates to the logical and emotional aspects of our personality. It purifies nadis, clears channels and blockages, and maintains thermostats.

\section{KAPALBHATI PRANAYAM}

Kapalbhati Pranayama is a breathing practice in yoga. When you exhale forcefully you try to take out all toxins from the body which enables you to enhance the immune system, and your intellect becomes refined and sharps.

This kriya is a breathing technique that strengthens your chest, cleanses your abdominal organs, and energizes your circulatory as well as nervous systems.

\section{Impact}

Kapalbhati pranayama helps you breathe correctly, and breathing correctly calms your mind. A calm mind tends to fall sound asleep quickly. It improves blood circulation in the whole body, boosts the immune system, cure diabetes, constipation, asthma, allergy, sinusitis, and kidney disorders. Purifies frontal sinus, rejuvenate whole body, keep face young [44].

\section{BHASTRIKA PRANAYAM}

Bhastrika means below, it is called "Bellow Breathing." Bhastrika Pranayama is the process of rapid inhalation and exhalation which gives a boost to the body and hence is aptly called the yogic breath of fire. Diaphragm and abdominal muscles draw air in and out of the lungs once practiced, and squeeze blood through the digestive organs which boosts heat in the body. This heat helps to keep the body warm and boost the immune system.

\section{Impact}

It balances Tri dosas, energizes the body and the mind, improves the function of the digestive and excretory organs along with enhancing digestive power, and cures cold, flu, sinus, asthma, and good for tonsil. It reduces stress and anxiety and increases concentration.

\section{BHRAMARI PRANAYAMA}

It is a calming breathing practice that soothes the nervous system and helps to connect us with our inner nature. Bhramari is the Sanskrit word 
for "bee," and this pranayama is so named because of the humming sound produced at the back of the throat during the practice - like the gentle humming of a bee.

It creates vibrations that stimulate the pituitary gland, pineal gland, and activate nerves across the brain and forehead.

\section{Impact}

It calms and quiets the mind, releases cerebral tension, stimulates the pineal and pituitary glands, soothes the nerves, relieves stress and anxiety, dissipates anger, lowers blood pressure, bolsters the health of the throat, strengthens and improves the voice, supports the healing of bodily tissues, and induces sound sleep.

\section{UDGEETH PRANAYAM (CHANTING BREATHING TECHNIQUE)}

The Sanskrit word "Udgeeth" means chanting. Udgeeth Pranayama is Om Kara chanting.

Omkara sound connects you with silence within you. In this silence, our brain gets vibrations to tune in a natural frequency.

\section{Impact}

It controls hypertension, improves nervous system, and increases memory power, concentration, positive thinking, and self-confidence, It improves blood circulation and relieves anxiety, tension, stress, and anger. It reduces insomnia, cures acidity, and improves the digestive system.

A strong approach is described in the literature about the "Pratipaksha Bhavana" [21] where "Pratipaksha" means opposite and Bhavana means thoughts or emotions. By this therapy, one can control the mind. This technique works on the mind toward positive thinking $[18,23]$.

\section{CONCLUSION}

Contemporary and traditional management together can improve the health of an individual as well as society keeping positive mind and a healthy body are the sources of contentment in the pandemic. Thus, adopting a holistic outlook, good lifestyle with appropriately balanced diet, Yoga, Pranayam, meditation, along with Achar Rasayan, and Sadvritta can led a stress-free living can prove to be an functioning management for COVID 19.

\section{CONFLICTS OF INTEREST}

None.

\section{REFERENCES}

1. Tillu G, Chaturvedi S, Chopra BP. Public health approach of ayurveda and yoga for COVID-19 prophylaxis. J Altern Complement Med 2020;26:129.

2. Das MA, Soni VM, Munjal N. Ayurveda and yoga: An immunity booster at the time of COVID-19 pandemic. Int J Res Eng Manag 2020;6:3-5

3. Worldometer. COVID-19 CORONAVIRUS PANDEMIC; 2020. p. 1. Available from: https://www.worldometers.info/coronavirus.

4. Garg DG. Covid-19 Pandemic the Ayurveda Perspective. J Crit Rev 2020;7:1-7.

5. Kamde S, Sawarkar G. Role of Ayurveda in communicable diseases (COVID-19). Int J Res Pharm Sci 2020;11:730-3.

6. Dubey S, Dubey R, Tripathi Y, Dadhich N. Preventive measures for communicable diseases in Ayurveda and ancient indian culture. Ann Ayurvedic Med 2020;9:130-7.

7. Raj P, Bhati KR. COVID-19:An Ayurvedic Perspective. Research Gate; 2020. p. 1-13. Available from: https://www.researchgate.net/ publication/345981721 COVID-19An ayurvedic perspective.

8. Andhare R, Muley S, Bhirange S. Ayurvedic perspective of Covid-19 diagnosis and management. J Crit Rev 2020;7:1070-2.

9. Sharma R. Prevention: Primary objective of Ayurveda TreatmentStemjar. Stemjar; 2019. p. 1-10. Available from: http://www.stemjar. com/ayurveda-and-prevention.
10. Gaus S, Kad V, Tupe M, Valsange A. Diagnostic importance of nidana panchak a review article. Int J Res Ayurveda Med Sci 2020;3:102-8.

11. Belgmwar V. The three main causes of disease in Ayurveda. Wellness Minneapolis; 2020. p. 1-3. Available from: https://www. wellnessminneapolis.com/articles/the-three-main-cause-for-disease-inaurveda. [Last accessed on 2020 Jun 11].

12. Samal J. Fundamental tents of epidemiology in ayurveda and their contemporary relevance. Indian Health Sci Biomed Res 2020;9:20-6.

13. Kamal B. Ayurveda and Covid-19. An Diego Ayurveda Healing California, USA. 2020. p. 1-6. Available from: https:// sandiegoayurvedahealing.com/ayurveda-and-covi-19. [Last accessed on 2020 Jun 11].

14. Samal J. Public Health importance of Shatkriyakala In Relation To Natural History Of Disease; 2013. p. 468-71. Available from: https:// www.core.ac.uk/reader/25761250.

15. Waghmare GA. Noval corona virus(2019-nCoV)-an ancient ayurveda epidemiology literature review. Ayurlog Natl J Res Ayurved Sci 2020;8:1-8.

16. Neman KA. Review of entities in Covid-19 and its relevance with rachna sharir. World J Pharm Res 2020;9:713-9.

17. Gutao RP, Namburi UR, Kumar S, Khode, NV, Mahulkar DM Pathogenesis of COVID-19: A review on integrative understanding through Ayurveda. J Res Ayurvedic Sci 2020;4:105-11.

18. Trivedi P. A 8 fold indigenous approach for improving psychoimmunity: With special reference to COVID19 pandemic. Dev Sanskriti Interdiscip Int J 2020;16:16-21.

19. Shukla R, Dwivedi O, Jain J, Khuje S. Role of rasayan in communicable disease (Janapadodhwamsa). Eur J Pharm Med Res 2019;6:232-4.

20. Kush L, Dimri M, Rajwar VS. Rasayan Drugs Promise Better AntiCovid-19 Medications. Asian J Pharm Res Dev 2020;8:148-9.

21. Datta N, Pal M, Roy U, Mitra R, Pradhan A. A holistic and prophylactic approach against new infections like Covid-19. World J Pharm Res 2020;9:15.

22. Rajput DS. Evolution, Ayurveda, immunity, and preventive aspects for emerging infectious diseases such as COVID-19. Int J Res Pharm Sci 2020;11:86-93.

23. Nagendra HR. Yoga for Covid-19. Int J Yoga 2020;13:87-8.

24. Kumawat S, Verma A, Yadav KL. Achara Rasayana a behavioural therapy in ayurveda to promote health and happiness. Int J Ayurveda Pharm Res 2018;6:44-9.

25. Sharma N, Sharma A, Yadav KC. Role of ayush in India's battle with COVID-19 pandemic: A review. Sch Int J Tradit Complement Med 2020;3:165-8

26. Bekal S. Corona Virus: Ayurvedic Analysis, Possible Prevention, Treatment Principles, Remedied. Easy Ayurveda; 2020. p. 1-30. Available from: https://www.easyayurveda.com/2020/03/16/coronavirus-ayurvedprevention-treatment. [Last accessed on 2020 Jun 11].

27. Sood T, Pathak M, Pathak SM. Vaad Chikitsa (Sound therapy) IN Sushruta Samhita Kalpa Sthana Chapter-3/13-15. World J Pharm Med Res 2020;6:136-41

28. Rawat D, Sharma A, Singh N, Kumar A. Holistic approach during a pandemic for healthy well-being holistic approach during a pandemic for healthy well-being. Indian J Nutr Diet 2020;57:329-40.

29. Pukale R, Sharma D, Bhakuni H, Krishnia KK. An integrative approach towards prevention and management of psychological illness during COVID-19 Crisis. J Ayurveda Integr Med Sci 2020;5:292-300. Available from: https://www.jaims.in.

30. Tewari S, David J, David B. A critical review on immune-boosting therapeutic diet against Coronavirus (COVID-19). J Sci Technol 2020;5:43-9. Available from: https://www.jst.org.in.

31. Deshmukh U. Concept of vihara in ayurveda a review article. Int Ayurvedic Med J 2017;5:3090-6.

32. Sadvritta AB. Code of right conducts in Ayurveda. World J Pharm Pharm Sci 2017;2017:449-58.

33. Sharma N. The Yoga for physical and mental health can possibly aid in prevention and management of COVID19 infection? Dev Sanskriti Interdiscip Int J 2020;16:22-31.

34. Phule S. Role of yoga in battling mental stress during lockdown. Mukt Shabd J 2020;9:2269-81.

35. Satuna RK, Negi A, Satuna R. Intuitive vision and indigenous immunity boosting approaches for COVID19: From the literature of pandit Shriram Sharma Acharya. Dev Sanskriti Interdiscip Int J 2020;16:1-15.

36. Yadav SK, Pathak A. Pranayama helps to boost immunity to fight against. Int J Physiol Phys Educ 2020;5:220-3.

37. Mishra A, Bentur SA, Thakral S. Integrative Therapy Based on Yoga and Ayurveda for Treatment of a High-risk Case of COVID-19/SARSCov-2 with multiple Co-Morbidities; 2020. 
38. Tiwari I, Singh Negi C. The relevance of yoga in developing holistic health and holistic community. Environ Conserv J 2019;20:83-8.

39. Pande P, Tendolkar V, Suraj S, Anjankar A. Yoga helps to improve immunity and fight against infection during Covid19. Indian J Forensic Med Toxicol 2020;14:7011.

40. Jackson WD. Covid19-A Nutritional, Herbal, and Spiritual Response Through Biospiritual Medicine; 2020. Available from: http://www. academia.edu/download/63125892/COVID19_-_A_Nutritional Herbal_and_Spiritual_Response_Through_B Biospiritual_ Medicine___William_Jackson_AHS_FSC_202020200428-20540or.pdf.

41. Venugopal V, Pamavathi R, Venkateswaran ST, Gunasekaran D. Protecting the elders from COVID- 19 impact-leveraging yoga The. J Fam Med Prim Care 2020;9:4487-8.
42. Valarmathi N, Sree RS, Rajan TS, Virudhunagar N, District M. Role of Antioxidant Herbs and Yoga Practices in Prevention of Infectious Diseases with special reference to Covid-19 Pandemic. Int J Res Pharm Sci. 2020;11(2):1902-7.

43. Barmola KC. Role of Bhastrika, Kapalbhati and Anulom Vilom Pranayam in Mental Health. In: Relevance of Mental Health during Covid-19; 2020. p. 1-6. Available from: https://www.researchgate.net/ profile/Kailash_Barmola/publication/341757037_Role_of_Bhastrika Kapalbhati_and_Anulom_Vilom_Pranayam_in_Mental_Health/ links/5ed2404392851c9c5e6670dc/Role-of-Bhastrika-Kapalbhati-andAnulom-Vilom-Pranayam-in-Mental-Health.pdf.

44. Sharma K, Anand A, Kumar R. The role of Yoga in working from home during the COVID-19 global lockdown. Work 2020;66:731-7. 